骖断しよ5と努力していますが，周知のように 稳状硬化と小動脈硬化は成因も病理もかなりち がい，これが差翼をも臨休診断上明らかにする 心要があります。まだ研究途上にありますので 皆様の御批判, 御教示をいただければ幸に有じ
ます。

終りに臨み本講演の機会を与えられた小野寺会長, 勝木準備委員長, 相沢座長ならびに教室の共同研究者 の各位に愿く感謝の意を表します。

\title{
3. 老年者の神経疾患（年令と神経疾患）
}

\section{1.はじめに}

老年期に和沪る神経疾患についてその頻度:は 極めて高い事は，我々も先に報告した所で女

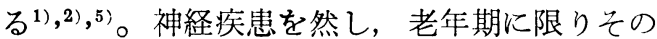
特性を見出す事は，病的現象を全体として取り 扱 といら点では不十分である ${ }^{3)}$ 。従つてここ では，神経疾患と加令との関係を全般的に追求 しその根拠にある病的現象を知ろうと試みた。

勿論，我々のこの成績は，臨床的記述的なもの であり，老年現象の根本にふれる為には，更に 次の段階が必要である。然しこの様な病的現象 について通覧したデータは現在十分であるとは 王えない。

\section{2. 材}

\section{料}

䄪 1200 例の最近儿大勝木内科を訪れた神経 病症例であり，内科的方面の材料の範囲の分析 には耐え得ると思われる。但し幼年期（10 才 以下）の疾患の分析には，福岡全市の疫学的調 査の症例を用いた。分析は主として発病年令に 基いて行つた。その理由は，之が最も発生病理 に関係すると思われるからである。

\section{3. 成 嘖}

1）神経疾患の年令的变化（大分類）

淃木内科の材料について，便宜的な大分類を 行つて見ると，図10如くである（実数で示し 心，10才以下は捨ててある。即ち疾患に上
九州大学助数授 黒 岩 義五郎

り, 発病年令分布が異る事が示され，その中で あ黒く塗つたカーブで示された疾患群（血管性 障害), 変性疾患, 脊髄疾患等は中, 老年期に 多く発病するものである。又斜線のカーブで示 された群（てんかん, 外傷性, 劧肉疾患, 機能

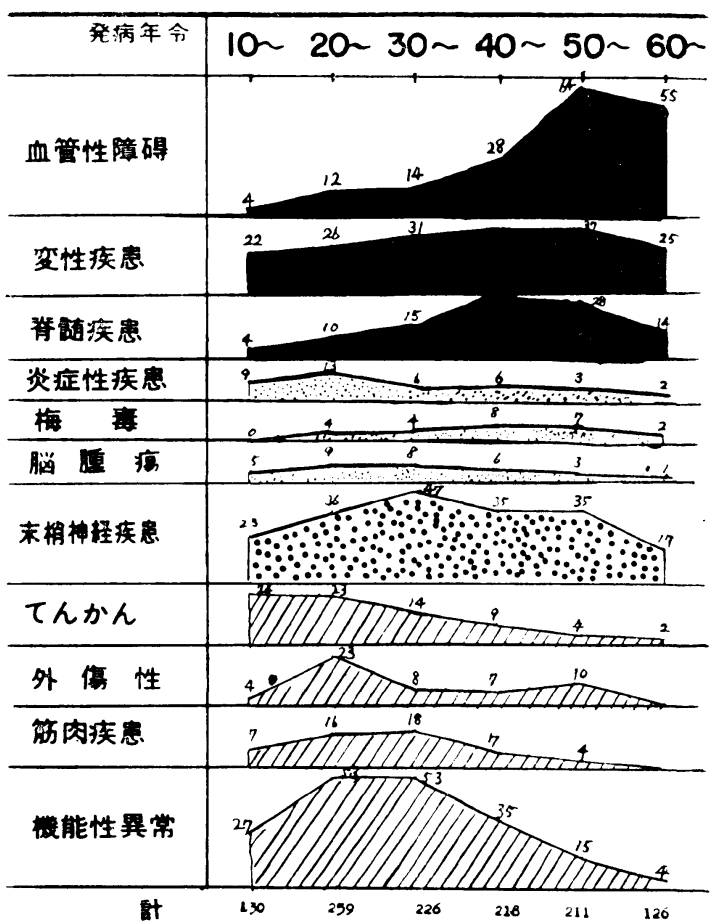

図 1 年令と神経疾患（大分類） 
性異常（メニェール，ナルコレブシー，片頭痛 等) は若年者の疾患である。又炎症性疾患でも 同椂の傾向が見られる。この様な患者の実数で 示す統計は各年代の患者の受診率が大きい要素 である事は否めず，又各年代別の総人口にも関 係をする。然しこの椂な大きい訂正すべき因子 を考虑に入れた上でも，相対的な一定の傾向の 存在は否定出来ない。

\section{2）各年代別の次患の比率の推移}

各年代別の疾患の比率を比べてみると, 図 2 の如くなる。即ち年代別全体の受診者総数を 100 とし，\%で示した。年令と共に増加する もの，又は中老年者で多い群は，血管性，変 性, 春髄, 梅毒, 末梢神経性等がその主なもの である。この数は発生病理に関係するというよ り寧ろ年代毎の実際的な主要疾患を示寸事に意 味があると思われる

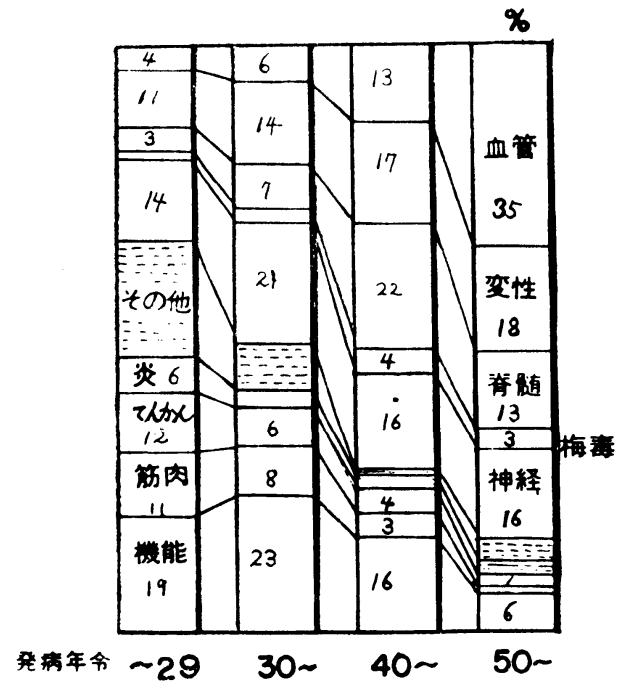

図 2 年代別神経疾患比率

3）個々の疾患群についての考察

変性疾患：内訳は図 3 の如くであり，パーキ ソソニズム, 筋萎縮性側索硬化症は中年以後に 多く発病する。之に対し.春髄性進行性筋萎縮症 はやや若年に多く, 又神経性進行性筋萎縮症, Wilson, 舞踏症は寧ろ若年者の疾患である。 又小脳変性症は若年, 中年に共ピークがみられ るが，中年以後のものは非遺伝性の小脳変性の

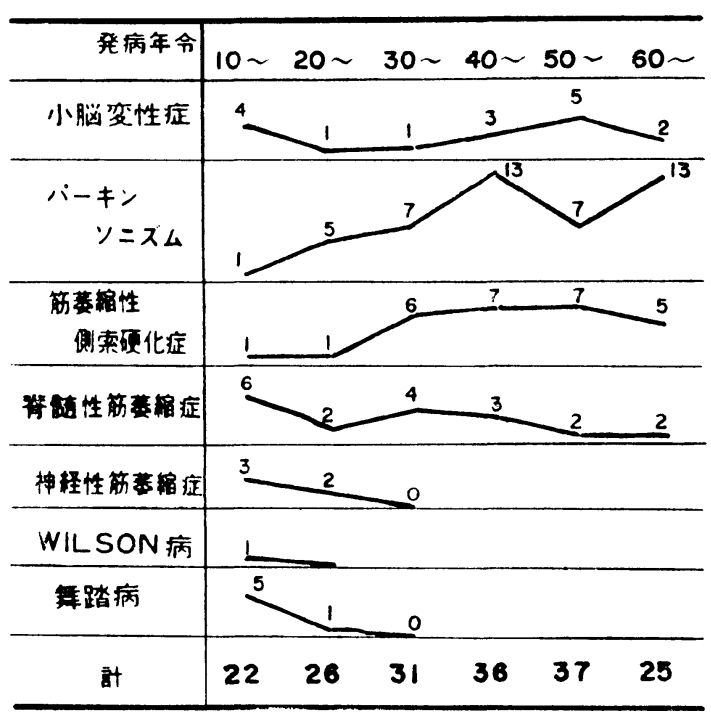

㲸 3 变性将患

みが主要なものである。

かくの如き変性疾患では変性が 1 つの系統の みならず，他の系統即ち錐体路系，錐体外路系 等も同時以変性する事が少なくなぐ，臨床的 分類又, 発生病理の考察等に重要な事実を提供 寸る。この様な多系統の变性に関係して最近グ アム島で見出された parkinsonism-dementia

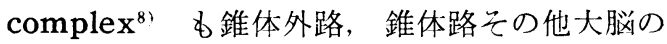
变性を同時に示し, 老年性又は presenile degeneration の pathoklisis を考える上にも 比較検討されるべきである

炎症性疾患（表 2)

急性脳炎（日本脳炎を除く）は10才以下の 表 1 感染・炎症性疾患（梅毒を除く） \begin{tabular}{|l|l|l|l}
$10 \sim 20$ & $20 \sim 30 \sim$ & 40 50 60
\end{tabular} 脳 炎 $4(2.2) * 2(0.8) * 1(0.4) * 1(0.5) * \ldots$ 脳

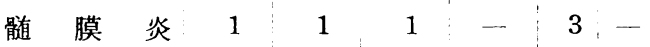

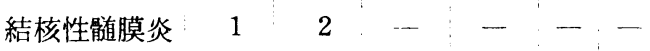

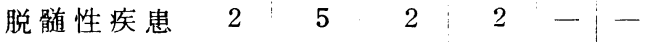

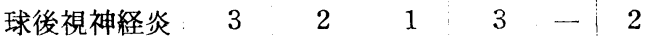
\begin{tabular}{ccc|c|ccc|c|c} 
ポ リ & オ & 1 & 1 & - & - & - & - \\
そ & の & 他 & 1 & - & 1 & - & - & - \\
\hline & & 14 & 13 & 6 & 6 & 3 & 2 \\
\hline 計 & & $(7.6 \%)$ & $(5.0)$ & $(2.7)$ & $(2.7)$ & $(1.4)$ & $(1.6)$
\end{tabular}

* 神経疾患中の比率 
奻児に压倒的に多く, 又髄膜炎等は明らかに若 年者に多い。又脱髄性疾患は若年成人の疾患で あり，老年者の疾患ではない。この椂に神経系 の急性庈応を伴う疾患は, 老年期では少いので はないかと思われる。

慢性の疾患即ち神経梅瑇は年令と共に増加す る事は当然であるが，之は社会的な理由にもよ ると思われる。

脊髄疾患（表 2)

之は年令と共に増加するが，特に脊椎性の原 因によるものが中年以後に多い。之は頸部苻椎 㾚が最近注目されてきた ${ }^{9), 107 。 ~}$

表 2 脊能道曹

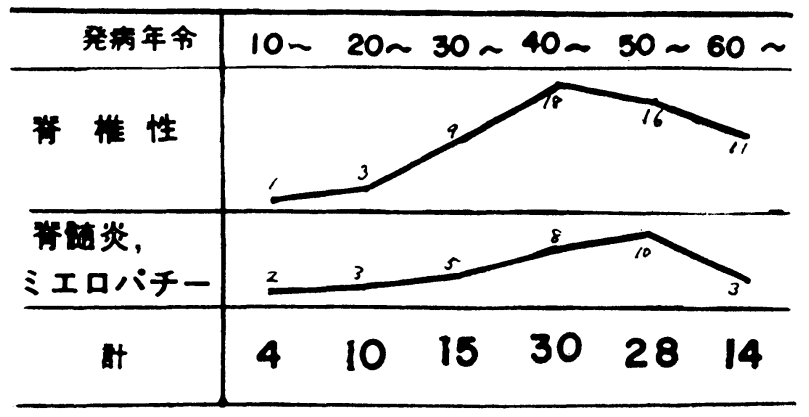

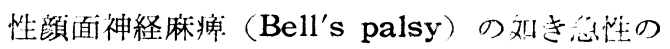
麻瘦は若年者特に 20 才代にどークを示し。 中，老年では少いと思われる

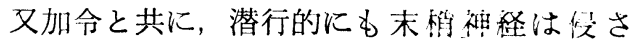
れ，その一例を示すと尺骨神経公導速度が 50 才以上では減少する。この傾问は糖梁病者では より著明にみられる。この様に二ニーロパチー は中老年者では少なくないが，穴の原因的分析 は俴々困難である。

筋肉疾患

之は表 3 に示した如く一般に笘售者に多いも のである。筋ジストロフィー症の発病年命は福 岡市内の全症例で見ると, 10 才以下に 多く(図省略), 幼小无が大部分であ る。又周期性四肢麻痺なども成年期の 男子の疾患で，老年性の桨患ではない と思われる。

然し 30 才以後におこる能䛈患（ミ オパチー) は遅発性ミオパチー(Late myopathy）とも云われている。又 Shy は之を Late onset symmetrical progressive polymyopathy

頸部脊椎症の臨木（概要）

主要自覚症状は 36 例中上肢しびれ $(83 \%)$, 新部痛 $(55 \%)$, 歩行障害 (58\%), 放散痛 (47 \%) である。他覚的徵候は上肢脱力（55\%), 上肢深部反射立進 $(11 \%)$, 筋萎縮 $(22 \%)$, 下 肢脱力 $(36 \%)$, 下肢錐体外路徵候 $(33 \%)$, 知 覚レベル $(11 \%)$ となつている。即ち, 中, 老 年期にみられる上肢のしびれ, 頸肩部痛, 下肢 不全麻痺の時には本症の可能性を考えなければ ならない。頸部運動による放散痛は背屈時に多 く, 次いで前屈時等におこり, 放散の方向は背 部へ又は上肢へ放散するものが多く，肩部に止 まるものが之に次ぐ, 又頸運動による矓量等の 脳幹症状を示すことも時にある。臨床的の病型 は多彩であり, 私共は之を頸型, 上肢型, 下肢 型，上下肢型と四型に分けたが $2 / 3$ は上下肢型 である。

\section{末梢神経疾患}

之は年令を問わずに同樣に見られるが，末梢
表 3 訜肉疾患

\begin{tabular}{|c|c|c|c|c|c|c|c|}
\hline 発 病 年 令 & $0 \sim$ & & $20 \sim$ & 30 - & $10-$ & $50 \sim$ & $60 \sim$ \\
\hline 筋ジストロフィー & 5 & 1 & 3 & 2 & - & - & - \\
\hline 筋 強 直 症 & 1 & 2 & 2 & 0 & 1 & - & - \\
\hline 重症筋無力症 & 1 & - & 4 & 3 & 1 & 3 & - \\
\hline 周期性麻㽻 & 1 & 4 & 5 & 4 & 2 & - & 一 \\
\hline 管 & - & - & - & 6 & 1 & 1 & - \\
\hline 他 筋 萎 縮 & 一 & 一 & 2 & 3 & 2 & - & - \\
\hline 計 & 8 & 7 & 16 & 18 & 7 & 4 & 0 \\
\hline
\end{tabular}

と呼んでいるが，その原因は，30～50 才の間と 50 以後の発病群では非常に異つて剧り, 30〜50 才の発症例では, 膠原病に属するとされている 皮膚筋炎, 硬皮症, 結節性多発性動脈炎, リ二 一マチ性関節炎, 散在性疮瘡等に伴 5すのが多 いが, 50 才以後の発病例では, 悪性腫煌による ものがその 40\%を占めて居る(carcinomatous myopathy)（Shy）又女子では曼性筋炎の一 つである閉経期性筋ジストロフィ一棹も考虑さ 
れるべきである。

以上各疾照别について逨べたので，次に各惊 候汶に述べる。

\section{4）症候と年令との関係}

意識障害 : „つ神経疾患中で起る割合は, 加 令と共に減少の傾向にある。却ち意識障害は老 作者神経疾患の特質ではない。その原因的に見 ると，30 才以下の喏年者ではてんかんによる ものが $2 / 3$ を占めるが，老年期では血管性障害 比るのが多い。

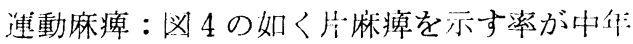
以後の神経疾患に多くなつて居り, 対麻痻は年

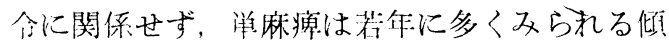
攸にある。

図 4 運動麻凂

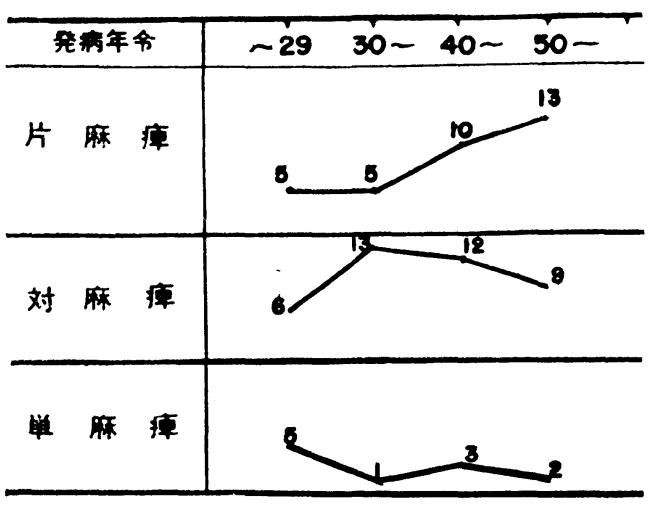

(\%)

表 4 対麻痺の原因

\begin{tabular}{|c|c|c|c|c|}
\hline 発 病 年 令 & $\sim 29$ & $30 \sim$ & $40 \sim$ & $50 \sim$ \\
\hline 頸 部 脊 椎 痁三 & - & 2 & 7 & 8 \\
\hline 答瓷髄炎 & 1 & 2 & 2 & 6 \\
\hline 疭性脊骫有 麻 痺 & 4 & 7 & 4 & 4 \\
\hline 軠 䯣 梅 毒 & 1 & - & - & 2 \\
\hline 等䯣腫煌 & 2 & - & 1 & 1 \\
\hline 他等髄疾患 & 3 & 2 & 5 & 3 \\
\hline 脑動脈硬化 扰 & - & - & - & 2 \\
\hline 散在性脳脊骾炎 & 4 & 1 & 1 & - \\
\hline 多発性神経 炎 & 5 & 4 & 3 & - \\
\hline 湩動ニニーロン疾患 & 2 & 4 & 1 & - \\
\hline 脳性小览磨痺 & 6 & - & - & - \\
\hline 九 $\quad$ の 他 & 1 & 2 & 2 & 1 \\
\hline 郭 & 27 & 29 & 27 & 29 \\
\hline
\end{tabular}

片麻痺の起つたものの原因を年令別に見る と，血管性の原因は 50 才以後では $98 \% ， 40$ 才代では $81 \% ， 30$ 才代では $73 \% ， 30$ 才以下 では $32 \%$ となつて居り，老年期ではその殆ん ど大部分が敛血管性障軣によると公つて差支え ないが，若年期においてては多彩な原因による事 が分る。

対麻痺の原因的分析を表 4 亿示与と, 项部苻 惟症, 脊咀炎, 又は原因不明の痙性脊䯣麻痺が 中年以上に多い様である。老年期に括こる Gowersによつて云われた senile paraplegia は やはり多因子性の拉仯群である。

雓体外路系症状

正常老年者でも仮泊状顔貌，軽度の朌強甽， 連動の緩強等の錐体外路系の症状が認められる 事はすでに知られている (Critchley) $)^{3)}$ が, 中, 老年者ではパーキンンニズム, 振戦, 能強 㴊等の kinetic hypertonic syndrome が主 であり ${ }^{14)}$ ，之に対して舞踏病，アテトーゼ，ジ ストニーの様な症候群，則ち hyperkinetic hypotonic syndrome は稀である。この所謂 新線状体症候群が老年者では稀であると云う 事実と，老年者脳の新線状体に血管性障害が多 いと公う事奏㬏とは泩目すべきことであり，そ の説明として老年者の脳の機能が若年者とは具 つた反心を六すのではないかと云う可能性も考 えられる。特にかかる錐体外路系の症状は二次 的な解放現象とされているので，脸の各部位の 機能的な平衡が大きい影響を示寸と思われるか 表 5 錐体外路症状

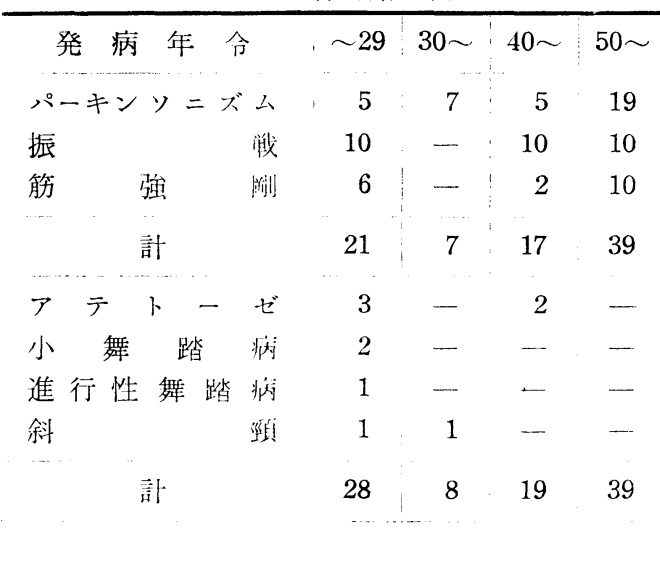


ウである。

然し老年者でもアテトーゼ様運動が伋性アテ トーゼとして，片麻痺の時に伴う事がある。之 泣位置覚の脱失した時にみられる。又視床傷害 の時に視床手としてアテトーゼ様運動が見られ る事むある。

\section{運動失調}

之は若年期にも老年期にも起る。然しその原 汹が異つて扣り, 老年期では約半数が変性疾患 によるものであり, 若年期では腫瘍その他多く の原因によものが見られる。

\section{筫 萎 縮}

秎肉疾患については，前に述べた如くである が，50 才以上で発病する筋萎縮 15 例を疾患別 に見ると，運動ニューロン疾患 4 例，二ューロ 乎-5 例, 脊髄疾患 2 例, 頸部脊椎症 2 例々 の他となつて居り, 以上凡て類似の病像を示す ことが少なくない。中老午者で特に手筋の萎縮 の場合, 予後の恶い運動二ューロン疾患と, 他 の良性のものとを爁别する事が実際的に重要で ある。

\section{5）病巣部位と年令との関係}

この様な神経疾患の病篗部位と年令との関係 は袁 6 の如くであり, 50 才以後発病者では大

表 6 病巣部位

\begin{tabular}{|c|c|c|c|c|c|c|}
\hline & \multicolumn{2}{|c|}{ 発病年令才 } & $\sim 29$ & $30 \sim$ & $40 \sim$ & $50 \sim$ \\
\hline 大 & & 脳 & $\begin{array}{c}57 \\
(15 \%)\end{array}$ & $\begin{array}{c}21 \\
(19 \%)\end{array}$ & $\left.\begin{array}{c}48 \\
(22 \%\end{array}\right)$ & $\begin{array}{c}119 \\
(35 \%)\end{array}$ \\
\hline 脳 & & 幹 & & 12 & & \\
\hline 小 & & 脳 & 10 & 2 & 2 & 4 \\
\hline 奉 & & 髄 & 37 & 39 & 49 & 59 \\
\hline 脳 & 神 & 経 & 47 & 26 & 20 & 26 \\
\hline 末 & 杪 神 & 経 & 55 & 39 & 35 & 43 \\
\hline 簕 & & 肉 & 19 & 9 & 6 & 4 \\
\hline 㩆做 & & 脂 & 5 & 5 & 4 & 5 \\
\hline 広 & & 沉 & 11 & 6 & 8 & 14 \\
\hline 機 & 能 & 性 & 144 & 66 & 48 & 47 \\
\hline そ & $の$ & 他 & 14 & 3 & 7 & 2 \\
\hline 総 & 例 & 数 & 443 & 226 & 218 & 337 \\
\hline
\end{tabular}

脳が多く(119/337，35\%)，之はより若い年代 のそれとは明らかに異る。勿論これからは老年 性神経疾患に括汁る pathoklisisについて云々
与る事は泝来ないが，大脸が経年的な变化を介 して俊され易いのではないかとも考えられる。

\section{綜括, 考按}

以上年令と神経疾患との関係について述べ, 中，老年期の神経疾患の特質を明らかにしよう と試みた。

老年者に拈いては糖尿病, 高血生, 動脈硬化 等の慢性状態 (chronic state) が高率に共存 し，之が神経異常の原因となり，又は之を修飾 し，その為に神経症状の原因的分析がきわめて 困難の事が少なくない。従つて純粋の老年性変 化とは何かと云う事が大きい問題となるが，こ こでは狭義の老年性変化の事はさておいて, 神 経異常を現象的に扱つてみた。勿論これからは 疾患個々の年令別人口選択性 (population selectivity）を推定する事は出来ないが，老年 者神経疾患に関する病態の概念の一部を知る事 が出来ると思う。且つ之は疾患の発生病理, 脎 の反応性，治潦対策等に関する基碟的な事䒠を 提供すると思われる。

神経疾患と加令との関係を検讨し，中老件期 の神経疾患の特質を明らかにしょうとした（内 科的方面の材料により)。

(1) 中老年期で血管性障害, 变性将莣, 青髄 疾患等が増加する。

(2) 変性疾患はパーキンソニズム, 連動二ュ 一ロン疾患が多い, 小脳変性は非遺伝性のもの が多い。

(3) 急性炎症性疾患は少い。

(4)脊髄疾患は奉椎性のものが増归する。頸 部脊椎症が重要な疾患である。

(5) 末梢神経疾患は増加しない。

(6) 筋肉疾患は符年性にないが, 遅発性ミミ才 パチーで癌性のものを注目すべきである。

(7) 症候として，片麻痺が増加し（主に血管 性), 又老年性対麻痻の原因は多梯である。錐 体外路症状は所謂 akinetic hypertonic syndrome が主である。筋萎絔を示寸ものには多 様のものがある。

(8)病镍部位は大脳が伀され易い。

(9)老华者では原因的分析が困難で离。 
御指導を戴い:勝木教授认感謝する。

\section{(協 力 者)}

荒不淑郎，宫崎募，梅崎博敏，川越博道，中 根和彥, 柇护由之, 称勢伊, 三田哲司, 加藤元 博, 问于正治

\section{文}

1. 黑岩義五郎：老年者の神経疾患比関与る蹦休病理 解剖学研究 (第 1 報) 臨床統部的研究, 脳と神経 $4: 263,1949$.

2. 勝木司馬之助, 黒岩義五郎他: 神経疾患々年令 (疫学的研究) 老年病（臨時增刊） $6: 310,1961$.

3. Critchley, Macdonald : Neurologic changes in the aged. J. of Chron. Dis. 3:459, 1956.

4. Critchley, M. : The neurology of old age, Lancet $1: 1119,1221,1131,1931$.

5. 尼子富士郎：老年者の生理病理と臨床, 第 13 回 日本医学会会誌.

6. 椿忠雄, 亀山正邦：老年期の神経系, 老年病学, 金原, 1957.

7. 黒岩義五郎他：小脳变性疾患儿打ける錐体路症 状, 精神从経誌 $64: 394,1962$.
8. Hirano, A., Kurland, L.T., Krooth, R. S. and Lesse I, S. : Parkinsonism Dementia Complex, an endemic disease on the island of Guam. 1. Clinical feature, Brain $84: 662$, $1962: 2$. Pathological features, ibid. $84: 662$, 1962.

9. Brain. W. R., Northfield, D. and Wilkinson, M. : The neurological manifestations of cervical spondylosis, Brain $75: 187-225,1952$.

10. 岩田金次郎: Spondylosis による Cervical Myelopathy 臨床神経学 $2: 245,1962$.

11. Shy. M. : The Late onset Myopathy, World Neurology $3:$ 149, 1962.

12. Gowers' W. R. : Centralbl f. Nervenk. u. Psych. 1890.

13. Kelly, A. O. J. : Senile paraplegia J. Nerv. \& Ment. Dis. $23: 713,1896$.

64. 黒岩義五郎他：神経疾患の臨床病理学的研究, 彩 13 報, 線状体傷害について, 脳と神経 $4: 283$, 1952.

15. 冲中重雄他: 視床賃害の臨床病理学的考察, 石橋: 編, 間脳の機能と臨床, 216,1953 医学津院.

\section{4. 老年者の脳及び亦䯣の血管性障害の予後に関する 2,3 の問題}

東京大学冲中内科塚越㕕

\section{I. 緒言}

脸の血管性障害については多くの報告がある が，今回は脸及び奉髄の血管性障害の予後に関 する 3,3 の問題, 特に老年者の屈曲性対麻痺 について浴風会の症例を中心に検尉してみる。

\section{II. 脳室出血の予後}

臨床的並びに病理解剖学的に脳窒出血と晾断 された 63 例についてみると，既に発表した如 く ${ }^{1)}$, 発作後 24 時間以内に 33 例 $52 \%, 10$ 日 以内に 58 例 $92 \%$ ，1月以内に 60 例 $95 \%$ が 死亡していて网空出血の生命に対する予後は極
めて覀い。しかし，これは発作時の㫌状の明ら かな症例についての統計である。これを更に拡 げて，発作時の症状のそれ程明らかでないもの をる加えると, 脳窒出血後 1 カ月以上生存した 例が 17 例に達した。この 17 例の原発出血巣を みると, 視床出血から側脳室に破れるものが 10 例，小脳歯状核附近の出血から第 4 脸室に破れ るものが 4 例, 大脳白質出血から側脳空に破れ るものが 2 例, 外包附近の出血で側脸空に破れ たものが 1 例であつた。

症例 1 は 71 才の女で 1955 作 8 月 31 日潮 